\title{
Serological Properties and Immunobiological Activities of Lipopolysaccharides from Black-pigmented and Related Oral Bacteroides Species
}

\author{
By TAKU FUJIWARA, ${ }^{1}$ TATSUJI NISHIHARA, ${ }^{1}$ TOSHIHIKO KOGA ${ }^{1}$ \\ AND SHIGEYUKI HAMADA ${ }^{2 *}$ \\ 'Department of Dental Research, The National Institute of Health, Kamiosaki, Shinagawa-ku, \\ Tokyo, 141, Japan \\ ${ }^{2}$ Department of Oral Microbiology, Osaka University Faculty of Dentistry, Yamadaoka, \\ Suita-Osaka, 565, Japan
}

(Received 8 June 1988; revised 1 August 1988)

\begin{abstract}
Lipopolysaccharides (LPS) from five species of oral Bacteroides, B. gingivalis strains 381 and ATCC 33277, B. oralis ATCC 33269, B. loescheii ATCC 15930, B. intermedius ATCC 25611 and $B$. corporis ATCC 33547 , were extracted from whole cells by the phenol/water procedure, and subsequently purified by treatment with nuclease and ultracentrifugation. The LPS were composed of hexoses, glucosamine, fatty acids and phosphorus. Heptose and 2-keto-3deoxyoctonate were not detected. The LPS preparations from $B$. gingivalis strains 381 and ATCC 33277 presented very similar SDS-polyacrylamide gel electrophoresis patterns when stained with ammoniacal silver. They produced a fused precipitin band against an antiserum to $B$. gingivalis 381 LPS in immunodiffusion tests. Antisera raised against the LPS from $B$. loescheii and $B$. intermedius reacted with the LPS prepared from all the oral Bacteroides strains except those of $B$. gingivalis. All the LPS preparations were mitogenic for spleen cells of BALB/c $(\mathrm{nu} / \mathrm{nu})$ mice, but not for thymus cells from $\mathrm{C} 3 \mathrm{H} / \mathrm{HeN}$ mice. The LPS induced marked mitogenic responses and polyclonal $\mathrm{B}$ cell activation for spleen cells of not only $\mathrm{C} 3 \mathrm{H} / \mathrm{HeN}$ (LPS responder) mice, but also $\mathrm{C} 3 \mathrm{H} / \mathrm{HeJ}$ (LPS nonresponder) mice. The mitogenic responses were not suppressed significantly upon addition of polymyxin B to the reaction mixture. These LPS also enhanced interleukin-1 production by murine peritoneal macrophages and mouse cell line J744.1 macrophages. Hydrolysis of $B$. gingivalis ATCC $33277 \mathrm{LPS}$ in $1 \mathrm{M}-\mathrm{HCl}$ at $100^{\circ} \mathrm{C}$ for $1 \mathrm{~h}$ yielded lipid and polysaccharide. The lipid portion was largely composed of fatty acids and glucosamine, and was mitogenic for spleen cells from $\mathrm{C} 3 \mathrm{H} / \mathrm{HeJ}$ as well as $\mathrm{C} 3 \mathrm{H} / \mathrm{HeN}$ mice, while the polysaccharide portion induced no significant mitogenic responses under similar experimental conditions.
\end{abstract}

\section{INTRODUCTION}

It has been suggested that dental plaque in the subgingival crevice is the major aetiological factor in the development of periodontal disease. Certain species of black-pigmented oral Bacteroides are suspected to be major causative agents of adult-type periodontitis, the most prevalent type of periodontal disease in the elderly. Among these, Bacteroides gingivalis and $B$. intermedius have been considered highly important in the pathogenesis of advancing periodontitis (Duerden et al., 1987; Mayrand \& Holt, 1988; Slots \& Listgarten, 1988). The major habitat for these bacterial species in the oral cavity is the subgingival crevice area. Some cellular

Abbreviations: Con A, concanavalin A; FCS, foetal calf serum; HBSS, Hanks' balanced salt solution; IL-1, interleukin-1; KDO, 2-keto-3-deoxyoctonate (3-deoxy-D-manno-2-octulosonic acid); LPS, lipopolysaccharide; PFC, plaque-forming cells; SRBC, sheep red blood cells. 
and extracellular components of oral Bacteroides species may occasionally induce inflammatory responses in the periodontal tissues, leading to the destruction of the tissues. A ubiquitous cellular component of Gram-negative bacteria, including oral Bacteroides species, is endotoxic lipopolysaccharide (LPS). LPS can elicit a plethora of immunobiological and pharmacological effects in host tissues, including the periodontal tissues (Daly et al., 1980; Morrison, 1983; Westphal et al., 1985). Higher levels of LPS have been demonstrated in extracts of dental plaque and root surface materials from patients with periodontal disease than from healthy controls (Daly et al., 1980; Wilson et al., 1986).

The chemical composition and some biological properties of the LPS from oral and non-oral Bacteroides species have been reported by several groups, demonstrating that both blackpigmented and non-black-pigmented Bacteroides species possess rather unusual LPS in terms of their chemical compositions and biological activities (Hofstad, 1974; Mansheim et al., 1978; Koga et al., 1985). However, no comparative examination of immunobiological properties of the various LPS from different species and strains of black-pigment forming Bacteroides of oral origin has been attempted. In this paper, we report results of immunochemical characterization and immunobiological studies on mitogenicity, polyclonal B cell activation, and interleukin (IL)-1 production of the LPS from several oral Bacteroides species in lymphoid cell cultures from LPS-responder and nonresponder mice.

\section{METHODS}

Bacterial strains and culture conditions. B. gingivalis ATCC 33277, B. oralis ATCC 33269, B. loescheii ATCC $15930, B$. intermedius ATCC 25611 and $B$. corporis ATCC 33547 were from our culture collection. Organisms of each test strain were cuitured anaerobically in a complex medium supplemented with haemin $(5 \mathrm{mg}$ $\left.\mathrm{l}^{-1}\right)$ and menadione $\left(1 \mathrm{mg} \mathrm{l}^{-1}\right)$ at $37^{\circ} \mathrm{C}$ for $2-4 \mathrm{~d}$, as described by Koga et al. (1985). After cultivation, cells were harvested by centrifugation, washed with pyrogen-free water, and lyophilized.

Preparation of LPS. LPS was extracted from lyophilized cells of the above strains by the phenol/water method (Westphal \& Jann, 1965). The crude extract dissolved in pyrogen-free water was collected by ultracentrifugation at $100000 \mathrm{~g}$ for $3 \mathrm{~h}$. The resulting pellet was treated with nuclease P1 (Yamasa Shoyu Co.) and purified by repeated ultracentrifugations as described previously (Koga et al., 1985). Chemical analyses were done as described by Koga et al. (1985). In some instances, the LPS preparation was retreated with phenol/water up to four times in order to obtain purer preparations. The lipid and the polysaccharide portions of LPS were obtained by hydrolysing LPS $\left(1 \mathrm{mg} \mathrm{ml}^{-1}\right)$ in $1 \mathrm{M}-\mathrm{HCl}$ at $100^{\circ} \mathrm{C}$ for $1 \mathrm{~h}$, and chemical analyses were done as described above. The LPS of B. gingivalis 381 and Escherichia coli K235 were also used for reference in some experiments. The chemical characterization of these two LPS preparations was reported by Koga et al. (1985).

$S D S$-polyacrylamide gel electrophoresis (SDS-PAGE). SDS-polyacrylamide slab gels, with $12.5 \%(\mathrm{w} / \mathrm{v})$ resolving and $4 \%(\mathrm{w} / \mathrm{v})$ stacking gels, were prepared as described by Laemmli $(1970)$. LPS $(100 \mu \mathrm{g})$ was heated at $100^{\circ} \mathrm{C}$ for $5 \mathrm{~min}$ in $10 \mathrm{mM}$-Tris/ $\mathrm{HCl}$ buffer (pH 8.0) containing $2.5 \%(\mathrm{w} / \mathrm{v}) \mathrm{SDS}, 5 \%(\mathrm{v} / \mathrm{v}) 2$-mercaptoethanol, $1 \mathrm{~mm}$-EDTA, and $20 \%(\mathrm{v} / \mathrm{v})$ glycerol. Electrophoresis was performed at $150 \mathrm{~V}$ constant voltage for $5 \mathrm{~h}$. The LPS bands were visualized by staining with ammoniacal silver (Tsai \& Frasch, 1982) or Coomassie brilliant blue.

Immunodiffusion. The Ouchterlony method of double diffusion in Noble agar (Difco) was performed. Antisera against LPS of B. gingivalis $381, B$. loescheii and $B$. intermedius were obtained from New Zealand White rabbits which had been immunized by intramuscular injections of each LPS. LPS $(1 \mathrm{mg})$ was suspended in $1 \mathrm{ml}$ saline and mixed with an equal volume of Freund's complete adjuvant (Difco), and injected into the dorsal muscles of both sides of the trunk. This injection was repeated three times at 2-week intervals. After the immunization, the rabbits were bled from the central artery of the ear. The antisera were stored at $-20^{\circ} \mathrm{C}$ before use.

Mice. $\mathrm{BALB} / \mathrm{c}(\mathrm{nu} / \mathrm{nu}), \mathrm{C} 3 \mathrm{H} / \mathrm{HeN}$ and $\mathrm{C} 3 \mathrm{H} / \mathrm{HeJ}$ mice (all male) were obtained from the Department of Dental Research, The National Institute of Health, Tokyo. Spleen cells were obtained from mice aged 6-12 weeks; thymus cells were obtained from mice aged 4-6 weeks.

Lymphoid cell cultures. Mouse spleen or thymus cells were prepared by gently homogenizing spleens or thymuses in RPMI 1640 (Gibco) containing penicillin $\left(100 \mathrm{U} \mathrm{ml}^{-1}\right)$, streptomycin $\left(0.1 \mathrm{mg} \mathrm{ml}^{-1}\right)$, L-glutamic acid $(2 \mathrm{mM})$ and HEPES buffer (15 mM, pH 7.2). This supplemented RPMI 1640 medium is referred to as RPMI-1640S. Cells $\left(7 \times 10^{5}\right)$ were cultured in $0.2 \mathrm{ml} \mathrm{RPMI}-1640 \mathrm{~S}$ with stimulants at $37^{\circ} \mathrm{C}$ for $48 \mathrm{~h}$ in a 96-well plate in a humidified atmosphere of air $/ \mathrm{CO}_{2}(95: 5, \mathrm{v} / \mathrm{v})$. Cultures were pulsed for the final $6 \mathrm{~h}$ incubation with $\left[{ }^{3} \mathrm{H}\right]$ thymidine $(0.25 \mu \mathrm{Ci}$, $9.25 \mathrm{kBq}$; Amersham). The cultures were then harvested onto glass-fibre strips with a multiple cell harvester, and counted in an Aloka scintillation counter. All stimulants were tested in triplicate on three separate occasions.

To determine the effect of polymyxin B on mitogenic responses of mouse spleen cells, cells $\left(7 \times 10^{5}\right)$ were cultured at $37^{\circ} \mathrm{C}$ for $48 \mathrm{~h}$ in $0.2 \mathrm{ml} \mathrm{RPMI}-1640 \mathrm{~S}$ containing $0-5 \mu \mathrm{g}$ polymyxin B (Sigma) and $5 \mu \mathrm{g}$ stimulant LPS. The incorporation of $\left[{ }^{3} \mathrm{H}\right]$ thymidine was quantified as described above. 
Polyclonal B cell activation by LPS was assayed in spleen cells cultured in vitro, as follows. Spleen cells $\left(1 \times 10^{6}\right)$

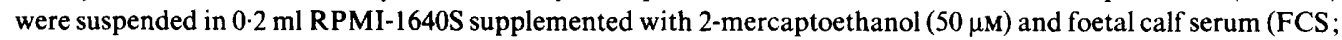
$10 \%, \mathrm{v} / \mathrm{v}$ ), and cultured with stimulant at $37^{\circ} \mathrm{C}$ for $96 \mathrm{~h}$ in a $96-w e l l$ plate in a humidified atmosphere of air $/ \mathrm{CO}_{2}$ $(95: 5, \mathrm{v} / \mathrm{v})$. Cells were then washed with Hanks' balanced salt solution (HBSS; Gibco), and tested for direct antisheep-erythrocyte plaque-forming cell (anti-SRBC PFC) responses by the haemolytic plaque assay technique of Cunningham \& Szenberg (1968).

$I L-1$ assay in macrophage cultures. Peritoneal macrophages were induced by intraperitoneal injection of $1.5 \mathrm{ml}$ thioglycollate medium (Difco) into $\mathrm{C} 3 \mathrm{H} / \mathrm{HeN}$ mice. Peritoneal exudate cells were collected $3 \mathrm{~d}$ later by peritoneal lavage with $5 \mathrm{ml} \mathrm{HBSS}$ containing $1 \%(\mathrm{v} / \mathrm{v})$ FCS (HBSS-FCS), washed, and resuspended to a density of $1 \times 10^{6}$ cells $\mathrm{ml}^{-1}$ in RPMI-1640S containing $5 \%$ (v/v) FCS. The murine macrophage cell line $\mathrm{J} 744.1$ was kindly provided by Drs K. S. Akagawa and T. Tokunaga, The National Institue of Health, Tokyo. The cells were cultured in RPMI- 1640 S containing $10 \%(\mathrm{v} / \mathrm{v}) \mathrm{FCS}$ at $37^{\circ} \mathrm{C}$ in air $/ \mathrm{CO}_{2}(95: 5, \mathrm{v} / \mathrm{v})$. The adherent cells were removed with a rubber policeman, washed with HBSS and resuspended to a density of $1 \times 10^{6}$ cells $\mathrm{ml}^{-1}$ in RPMI-1640S containing $5 \%(\mathrm{v} / \mathrm{v})$ FCS.

The suspensions of peritoneal exudate cells or $\mathrm{J} 744.1$ cells $(1 \mathrm{ml})$ were cultured in a 24-well plate (Corning) for $3 \mathrm{~h}$ at $37^{\circ} \mathrm{C}$, and nonadherent cells were washed off with HBSS-FCS. The adherent cells were incubated in RPMI$1640 \mathrm{~S}$ with or without stimulant at $37^{\circ} \mathrm{C}$ for $24 \mathrm{~h}$ in air $/ \mathrm{CO}_{2}(95: 5, \mathrm{v} / \mathrm{v})$. Supernatants were collected by centrifugation, filter-sterilized, and used for IL-1 assay. IL-1 activity in serial dilutions of the supernatant of the macrophage culture was determined by measuring the uptake of $\left[{ }^{3} \mathrm{H}\right]$ thymidine into $\mathrm{C} 3 \mathrm{H} / \mathrm{HeJ}$ mouse thymus cells $\left(1.5 \times 10^{6}\right)$ that were cultured in RPMI-1640S containing $10 \%(\mathrm{v} / \mathrm{v})$ FCS and a submitogenic dose of Con A $(1 \mu \mathrm{g}$ $\mathrm{ml}^{-1}$; Sigma $)$ in air $/ \mathrm{CO}_{2}(95: 5, \mathrm{v} / \mathrm{v})$. They were pulsed with $0.5 \mu \mathrm{Ci}(18.5 \mathrm{kBq})\left[{ }^{3} \mathrm{H}\right]$ thymidine during the final $18 \mathrm{~h}$ of a $72 \mathrm{~h}$ incubation period.

\section{RESULTS}

\section{SDS-PAGE of Bacteroides LPS}

The silver-staining profile of the LPS preparations from the five oral Bacteroides species studied is shown in Fig. 1. Each showed a series of closely spaced bands in a ladder pattern. The LPS profiles of $B$. gingivalis strains 381 and ATCC 33277 were almost identical. There were some intense low-molecular-mass bands in the LPS of B. oralis, B. intermedius, and B. corporis. No protein bands were stained with Coomassie blue after SDS-PAGE of the purified LPS (100 $\mu \mathrm{g}$ each) preparations (results not shown).

\section{Serological properties of Bacteroides LPS}

Immunodiffusion patterns of LPS preparations from the oral Bacteroides species are shown in Fig. 2. The LPS from B. gingivalis strains 381 and ATCC 33277 formed a fused precipitin band with antisera raised against LPS from $B$. gingivalis 381 , but no precipitin band was developed with antisera to LPS from other species. On the other hand, the LPS from B. oralis, B. loescheii, $B$. intermedius and $B$. corporis formed one or two precipitin bands against antisera raised against the LPS from $B$. loescheii and $B$. intermedius, respectively. Further, an additional precipitin band was seen when the antiserum raised against LPS from $B$. loescheii was reacted with the homologous LPS.

\section{Immunobiological activities of Bacteroides LPS}

The LPS preparations from $B$. gingivalis (two strains), B. oralis, $B$. loescheii, $B$. intermedius and $B$. corporis were mitogenic for spleen cells of $B A L B / c(n u / n u)$ mice but not for thymus cells of $\mathrm{C} 3 \mathrm{H} / \mathrm{HeN}$ mice (Table 1). In the control experiments, E. coli K235 LPS and Con A induced selective mitogenic responses in $\mathrm{BALB} / \mathrm{c}(\mathrm{nu} / \mathrm{nu})$ spleen cells and $\mathrm{C} 3 \mathrm{H} / \mathrm{HeN}$ thymus cells, respectively. These results indicate that the LPS from oral Bacteroides species are B cell mitogens.

LPS from all five Bacteroides species were similarly mitogenic for spleen cells from both $\mathrm{C} 3 \mathrm{H} / \mathrm{HeN}$ and $\mathrm{C} 3 \mathrm{H} / \mathrm{HeJ}$ mice (Table 2). The maximal mitogenic responses were obtained with LPS doses of 5-10 $\mu \mathrm{g}$ per well. The $E$. coli $\mathrm{K} 235$ LPS induced significant mitogenic responses in spleen cells of $\mathrm{C} 3 \mathrm{H} / \mathrm{HeN}$ mice, but not in those of $\mathrm{C} 3 \mathrm{H} / \mathrm{HeJ}$ mice. Polymyxin $\mathrm{B}$, a cationic antibiotic, suppresses the mitogenic effect of enterobacterial LPS in murine spleen cell cultures. The mitogenicity of $E$. coli LPS was markedly inhibited upon addition of increasing 


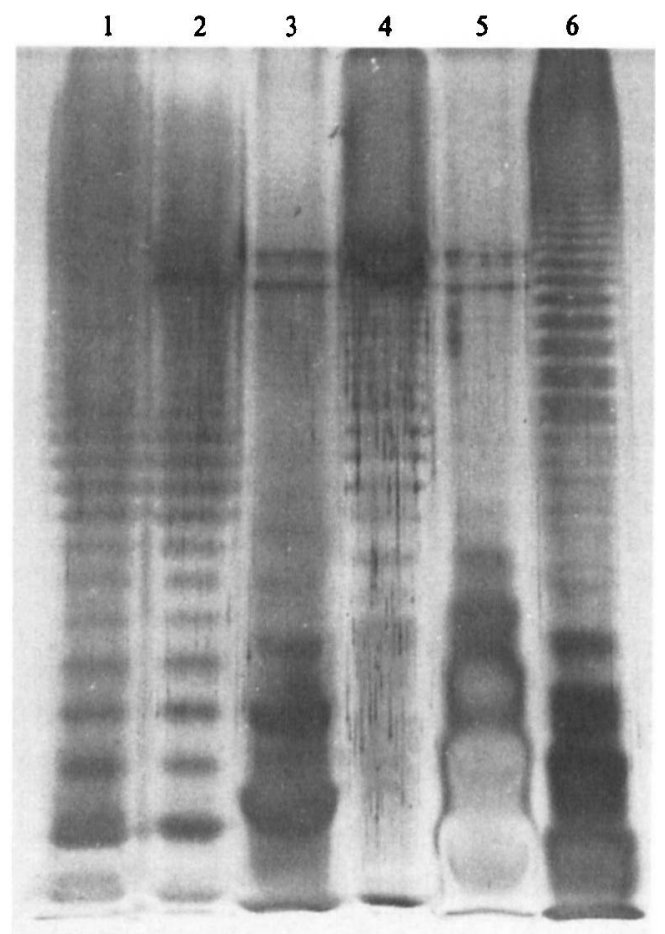

Fig. 1. Silver-stained gel after SDS-PAGE of LPS from oral Bacteroides species. Electrophoresis was performed in $12.5 \%(\mathrm{w} / \mathrm{v})$ acrylamide gel, containing $100 \mu \mathrm{g}$ LPS from B. gingivalis 381 (lane 1), B. gingivalis ATCC 33277 (lane 2), B. oralis ATCC 33269 (lane 3), B. loescheii ATCC 15930 (lane 4), B. intermedius ATCC 25611 (lane 5) and B. corporis ATCC 33547 (lane 6).

concentrations of polymyxin B. However, the Bacteroides LPS were only weakly affected by polymyxin B in terms of mitogenicity under similar experimental conditions (results not shown). These results, taken together, clearly suggest that the entity of Bacteroides LPS responsible for the mitogenic effect on murine spleen cells is different from that of enterobacterial LPS. The mitogenic activity of $B$. gingivalis ATCC $33277 \mathrm{LPS}$ in $\mathrm{C} 3 \mathrm{H} / \mathrm{HeJ}$ spleen cell culture was retained even after repeated treatment of the LPS preparation with phenol/water.

In addition to mitogenic activity, the Bacteroides LPS induced in vitro polyclonal B cell activation responses, as revealed by an increase in the number of anti-SRBC PFC in spleen cell cultures from $\mathrm{C} 3 \mathrm{H} / \mathrm{HeJ}$ and $\mathrm{C} 3 \mathrm{H} / \mathrm{HeN}$ mice (Fig. 3). E. coli $\mathrm{K} 235 \mathrm{LPS}$ induced polyclonal B cell activation responses in $\mathrm{C} 3 \mathrm{H} / \mathrm{HeN}$ spleen cell cultures but not in $\mathrm{C} 3 \mathrm{H} / \mathrm{HeJ}$ spleen cell cultures.

The Bacteroides LPS stimulated both peritoneal macrophages of $\mathrm{C} 3 \mathrm{H} / \mathrm{HeN}$ mice and cells of mouse macrophage cell line J744.1, resulting in the induction of IL-1 in the supernatants of these cell cultures (Table 3). The culture supernatants, at up to eightfold dilution, clearly enhanced the uptake of $\left[{ }^{3} \mathrm{H}\right]$ thymidine into the thymus cells cultured in RPMI-1640S with $10 \%$ (v/v) FCS and a submitogenic dose $\left(1 \mu \mathrm{g} \mathrm{ml}^{-1}\right)$ of Con A.

\section{Isolation of the lipid portion from LPS}

The LPS from B. gingivalis ATCC 33277 was treated in $1 \mathrm{M}-\mathrm{HCl}$ at $100^{\circ} \mathrm{C}$ for $1 \mathrm{~h}$ to dissociate the lipid A and polysaccharide portions of the LPS. The lipid portion was mainly composed of fatty acids $(70.5 \% \mathrm{w} / \mathrm{w})$, and glucosamine $(22.5 \%$, w/w); no hexose was found. However, treatment of the LPS with $1 \%(\mathrm{v} / \mathrm{v})$ or $5 \%(\mathrm{v} / \mathrm{v})$ acetic acid at $100{ }^{\circ} \mathrm{C}$ for up to $5 \mathrm{~h}$ did not result in significant amounts of insoluble precipitate. The lipid portion of $B$. gingivalis ATCC 33277 LPS was mitogenic for spleen cells of both $\mathrm{C} 3 \mathrm{H} / \mathrm{HeN}$ and $\mathrm{C} 3 \mathrm{H} / \mathrm{HeJ}$ mice, while the lipid A prepared 

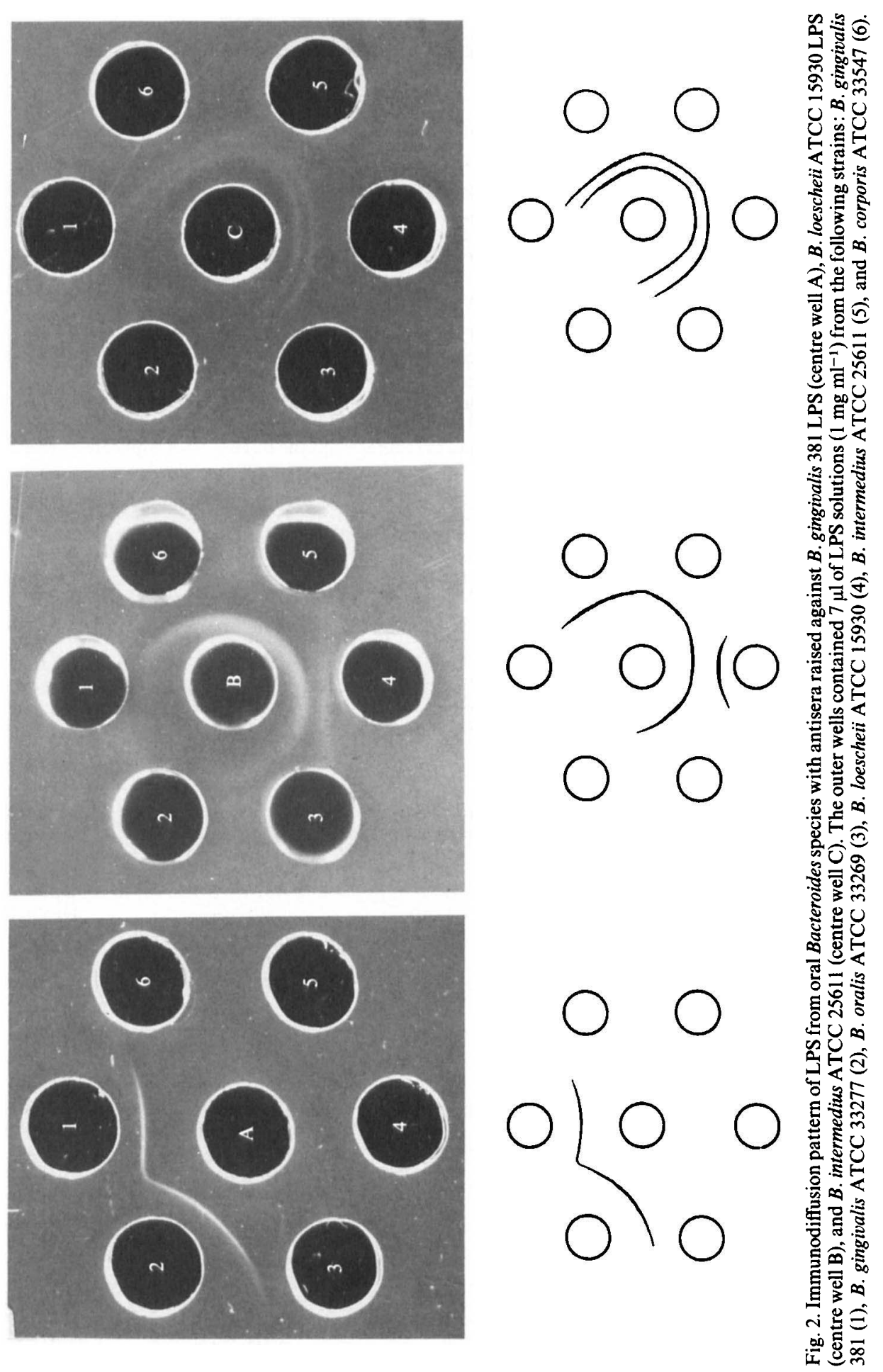


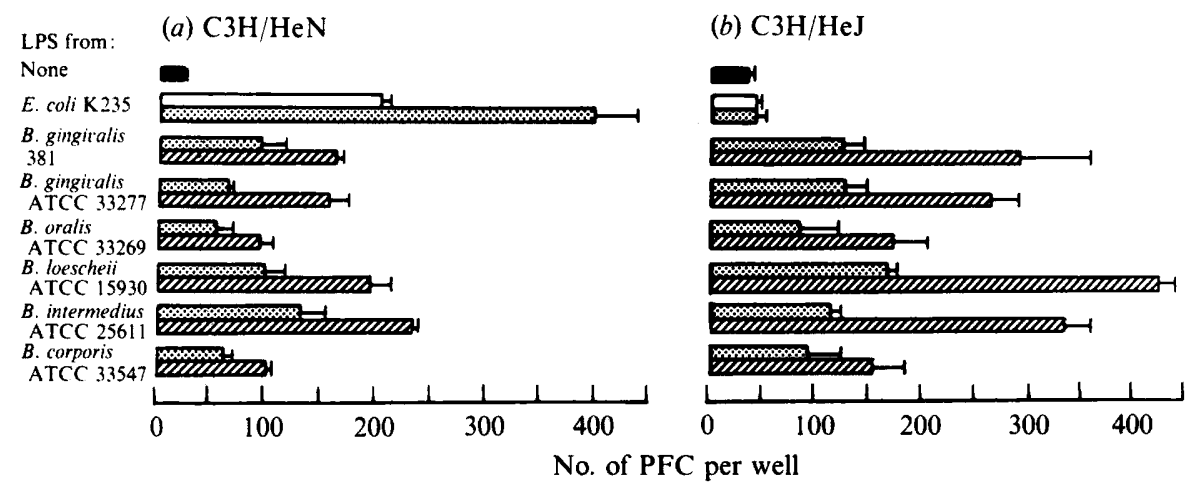

Fig. 3. Polyclonal B cell activation by LPS from Bacteroides species in spleen cell cultures from $\mathrm{C} 3 \mathrm{H} / \mathrm{HeN}(a)$ and $\mathrm{C} 3 \mathrm{H} / \mathrm{HeJ}(b)$ mice. Spleen cells $\left(1 \times 10^{6}\right.$ per well $)$ were incubated for $4 \mathrm{~d}$ with $0.02 \mu \mathrm{g}$ $(\square), 0.2 \mu \mathrm{g}$ ( with 2-mercaptoethanol $(50 \mu \mathrm{M})$ and $10 \%(\mathrm{v} / \mathrm{v})$ FCS. After $4 \mathrm{~d}$ incubation, anti-SRBC PFC responses were determined as described in Methods. Values are expressed as the mean \pm SD of triplicate cultures.

Table 1. Mitogenic responses of spleen cells from $B A L B / c(n u / n u)$ mice and thymus cells from $\mathrm{C} 3 \mathrm{H} / \mathrm{HeN}$ mice to $\mathrm{LPS}$ from oral Bacteroides species

Spleen cells $\left(7 \times 10^{5}\right.$ per well) from BALB/c $(\mathrm{nu} / \mathrm{nu})$ mice and thymus cells $\left(7 \times 10^{5}\right.$ per well) from $\mathrm{C} 3 \mathrm{H} / \mathrm{HeN}$ mice were incubated with LPS at $37^{\circ} \mathrm{C}$ in a humidified atmosphere of $5 \%(\mathrm{v} / \mathrm{v}) \mathrm{CO}_{2}$ in air. Cultures were pulsed with $0 \cdot 25 \mu \mathrm{Ci}\left[{ }^{3} \mathrm{H}\right]$ thymidine during the last $6 \mathrm{~h}$ of a $48 \mathrm{~h}$ incubation period. Values are expressed as the mean \pm SD of three different cultures.

Mitogen

None

Con A

E. coli K235 LPS

B. gingivalis 381 LPS

B. gingivalis ATCC 33277 LPS

B. oralis ATCC 33269 LPS

B. loescheii ATCC 15930 LPS

B. intermedius ATCC 25611 LPS

B. corporis ATCC 33547 LPS
Dose ( $\mu \mathrm{g}$ per well)

5

1

10

5

10

5

1

10

5

10

5

1

10

1

10

5

10

5

$\left[{ }^{3} \mathrm{H}\right]$ Thymidine uptake (c.p.m.)

$\begin{array}{cc}\begin{array}{c}\text { BALB/c (nu/nu) } \\ \text { spleen cells }\end{array} & \begin{array}{c}\text { C3H/HeN } \\ \text { thymus cells }\end{array} \\ 1020 \pm 248 & 240 \pm 24 \\ 1520 \pm 209 & 24187 \pm 1574 \\ 1596 \pm 68 & 1185 \pm 72 \\ 6492 \pm 427 & 363 \pm 8 \\ 13151 \pm 699 & 303 \pm 67 \\ 12793 \pm 1107 & 387 \pm 93 \\ 9560 \pm 1889 & 245 \pm 30 \\ 17320 \pm 1862 & 405 \pm 51 \\ 9229 \pm 849 & 312 \pm 82 \\ 7882 \pm 1007 & 378 \pm 3 \\ 5440 \pm 204 & 169 \pm 55 \\ 4775 \pm 491 & 182 \pm 30 \\ 16100 \pm 933 & 180 \pm 23 \\ 14602 \pm 892 & 188 \pm 15 \\ 8799 \pm 304 & 150 \pm 11 \\ 12793 \pm 2642 & 201 \pm 44 \\ 16062 \pm 1578 & 300 \pm 53 \\ 8799 \pm 304 & 150 \pm 11 \\ 31348 \pm 2748 & 141 \pm 10 \\ 28952 \pm 1908 & 120 \pm 19 \\ 6021 \pm 592 & 150 \pm 25 \\ 10124 \pm 642 & 142 \pm 27 \\ 7495 \pm 1492 & 174 \pm 105 \\ 3097 \pm 687 & 76 \pm 17\end{array}$


Table 2. Mitogenic responses of spleen cells from $\mathrm{C} 3 \mathrm{H} / \mathrm{HeN}$ and $\mathrm{C} 3 \mathrm{H} / \mathrm{HeJ}$ mice to LPS from oral Bacteroides species

Spleen cells $\left(7 \times 10^{5}\right.$ per well) from $\mathrm{C} 3 \mathrm{H} / \mathrm{HeN}$ and $\mathrm{C} 3 \mathrm{H} / \mathrm{HeJ}$ mice were incubated with $\mathrm{LPS}$ at $37^{\circ} \mathrm{C}$ in a humidified atmosphere of $5 \%(\mathrm{v} / \mathrm{v}) \mathrm{CO}_{2}$ in air. Cultures were pulsed with $0.25 \mu \mathrm{Ci}\left[{ }^{3} \mathrm{H}\right]$ thymidine during the last $6 \mathrm{~h}$ of a $48 \mathrm{~h}$ incubation period. Values are expressed as the mean $\pm \mathrm{SD}$ of three different cultures.

\begin{tabular}{|c|c|c|c|}
\hline \multirow[b]{2}{*}{ Mitogen } & \multirow{2}{*}{$\begin{array}{c}\text { Dose } \\
(\mu \mathrm{g} \text { per well) }\end{array}$} & \multicolumn{2}{|c|}{$\begin{array}{c}{\left[{ }^{3} \mathrm{H}\right] \text { Thymidine uptake (c.p.m.) }} \\
\text { by spleen cells from: }\end{array}$} \\
\hline & & $\mathrm{C} 3 \mathrm{H} / \mathrm{HeN}$ & $\mathrm{C} 3 \mathrm{H} / \mathrm{HeJ}$ \\
\hline None & - & $397 \pm 138$ & $413 \pm 39$ \\
\hline E. coli K235 LPS & $\begin{array}{r}10 \\
5 \\
1\end{array}$ & $\begin{array}{l}20769 \pm 1025 \\
25138 \pm 3561 \\
24956 \pm 2321\end{array}$ & $\begin{array}{l}729 \pm 57 \\
976 \pm 78 \\
873 \pm 61\end{array}$ \\
\hline B. gingivalis 381 LPS & $\begin{array}{r}10 \\
5 \\
1\end{array}$ & $\begin{array}{l}12809 \pm 692 \\
16461 \pm 1190 \\
13098 \pm 246\end{array}$ & $\begin{array}{l}16212 \pm 772 \\
24840 \pm 2208 \\
17809 \pm 1243\end{array}$ \\
\hline B. gingivalis ATCC 33277 LPS & $\begin{array}{r}10 \\
5 \\
1\end{array}$ & $\begin{array}{c}16461 \pm 1191 \\
13518 \pm 1165 \\
6267 \pm 706\end{array}$ & $\begin{array}{r}18322 \pm 917 \\
15573 \pm 983 \\
7522 \pm 448\end{array}$ \\
\hline B. oralis ATCC 33269 LPS & $\begin{array}{r}10 \\
5 \\
1\end{array}$ & $\begin{array}{l}17430 \pm 1607 \\
22039 \pm 3235 \\
16065 \pm 673\end{array}$ & $\begin{array}{l}10630 \pm 578 \\
11573 \pm 528 \\
10932 \pm 500\end{array}$ \\
\hline B. loescheii ATCC 15930 LPS & $\begin{array}{r}10 \\
5 \\
1\end{array}$ & $\begin{array}{l}20760 \pm 358 \\
20097 \pm 1115 \\
14889 \pm 1717\end{array}$ & $\begin{array}{l}19862 \pm 2623 \\
25291 \pm 2101 \\
20004 \pm 1268\end{array}$ \\
\hline B. intermedius ATCC 25611 LPS & $\begin{array}{r}10 \\
5 \\
1\end{array}$ & $\begin{array}{l}48030 \pm 4426 \\
32870 \pm 7144 \\
12541 \pm 358\end{array}$ & $\begin{array}{c}14820 \pm 1498 \\
13956 \pm 1335 \\
8204 \pm 204\end{array}$ \\
\hline B. corporis ATCC 33547 LPS & $\begin{array}{r}10 \\
5 \\
1\end{array}$ & $\begin{array}{c}16014 \pm 1126 \\
10330 \pm 63 \\
5007 \pm 830\end{array}$ & $\begin{array}{c}17992 \pm 956 \\
14307 \pm 1454 \\
6614 \pm 363\end{array}$ \\
\hline
\end{tabular}

Mitogen

None

E. coli K235 LPS

B. gingivalis 381 LPS

B. gingivalis ATCC 33277 LPS

B. oralis ATCC 33269 LPS

B. loescheii ATCC 15930 LPS

B. intermedius ATCC 25611 LPS

B. corporis ATCC 33547 LPS

1 $\left[{ }^{3} \mathrm{H}\right]$ Thymidine uptake (c.p.m.) by spleen cells from:

Table 3. Effect of LPS from oral Bacteroides species on IL-1 production by C3H/HeN peritoneal macrophages or cells of mouse macrophage cell line J744.1

Peritoneal macrophages $\left(1 \times 10^{6}\right.$ per well $)$ from $\mathrm{C} 3 \mathrm{H} / \mathrm{HeN}$ mice, or cells of mouse macrophage cell line J744.1 $\left(1 \times 10^{6}\right.$ per well), were incubated for $1 \mathrm{~d}$ with LPS $(25 \mu \mathrm{g})$ in $1 \mathrm{ml}$ RPMI 1640 medium. The macrophage culture supernatant and thymus cells $\left(1.5 \times 10^{6}\right)$ from $\mathrm{C} 3 \mathrm{H} / \mathrm{HeJ}$ mice were then cultured in $200 \mu \mathrm{l}$ RPMI 1640 supplemented with a submitogenic dose of Con $\mathrm{A}\left(1 \mu \mathrm{g} \mathrm{ml}^{-1}\right)$. Cultures were pulsed with $0.5 \mu \mathrm{Ci}\left[{ }^{3} \mathrm{H}\right]$ thymidine during the last $18 \mathrm{~h}$ of a $72 \mathrm{~h}$ incubation period. Values are expressed as the mean \pm SD of three different cultures.

$\left[{ }^{3} \mathrm{H}\right]$ Thymidine uptake (c.p.m.) by thymus cells

\begin{tabular}{|c|c|c|c|c|c|c|}
\hline \multirow[b]{2}{*}{ LPS from } & \multicolumn{3}{|c|}{$\begin{array}{l}\text { Dilution of culture supernatant } \\
\text { of } \mathrm{C} 3 \mathrm{H} / \mathrm{HeN} \text { peritoneal macrophages }\end{array}$} & \multicolumn{3}{|c|}{$\begin{array}{l}\text { Dilution of culture supernatant } \\
\text { of macrophage cell line } J 744.1 \text { cells }\end{array}$} \\
\hline & $1 / 2$ & $1 / 4$ & $1 / 8$ & $1 / 2$ & $1 / 4$ & $1 / 8$ \\
\hline None & $218 \pm 8$ & $289 \pm 97$ & $238 \pm 27$ & $421 \pm 28$ & $354 \pm 50$ & $306 \pm 25$ \\
\hline $\begin{array}{l}\text { B. gingivalis } 381 \\
\text { B. gingivalis ATCC } 33277 \\
\text { B. oralis ATCC } 33269 \\
\text { B. loescheii ATCC } 15930 \\
\text { B. intermedius ATCC } 25611 \\
\text { B. corporis ATCC } 33547\end{array}$ & $\begin{array}{l}3412 \pm 373 \\
2847 \pm 281 \\
3612 \pm 414 \\
3248 \pm 499 \\
3429 \pm 801 \\
3477 \pm 699\end{array}$ & $\begin{array}{l}1522 \pm 216 \\
1448 \pm 116 \\
2964 \pm 510 \\
1624 \pm 264 \\
2075 \pm 75 \\
2221 \pm 438\end{array}$ & $\begin{aligned} 751 & \pm 98 \\
869 & \pm 74 \\
1126 & \pm 333 \\
864 & \pm 27 \\
1660 & \pm 710 \\
719 & \pm 116\end{aligned}$ & $\begin{array}{l}4221 \pm 522 \\
4820 \pm 238 \\
3605 \pm 32 \\
4456 \pm 14 \\
4554 \pm 270 \\
3770 \pm 214\end{array}$ & $\begin{array}{l}2583 \pm 28 \\
2233 \pm 319 \\
2132 \pm 204 \\
3076 \pm 67 \\
2583 \pm 42 \\
2692 \pm 18\end{array}$ & $\begin{array}{r}938 \pm 189 \\
1498 \pm 168 \\
1169 \pm 196 \\
1278 \pm 298 \\
1540 \pm 220 \\
2653 \pm 242\end{array}$ \\
\hline
\end{tabular}


from $E$. coli $\mathrm{K} 235 \mathrm{LPS}$ was mitogenic only for $\mathrm{C} 3 \mathrm{H} / \mathrm{HeN}$ spleen cells, not for $\mathrm{C} 3 \mathrm{H} / \mathrm{HeJ}$ spleen cells. The polysaccharide portion of the LPS from B. gingivalis ATCC 33277 and E. coli K 235 did not exhibit significant mitogenic activity for the murine spleen cells.

\section{DISCUSSION}

LPS prepared by phenol/water extraction of whole cells of B. gingivalis was significantly different from that of Enterobacteriaceae species such as $E$. coli in terms of chemical composition, immunobiological activities, and toxicities (Koga et al., 1985, 1987). LPS of $B$. gingivalis, $\boldsymbol{B}$. intermedius and $\boldsymbol{B}$. fragilis are basically similar and possess no significant quantities of heptose and KDO (Hofstad, 1974; Johne \& Bryn, 1986; Koga et al., 1985; Mansheim et al., 1978). All the LPS preparations from the Bacteroides species used in this study possess various quantities of hexose, glucosamine, fatty acid and phosphorus, but no detectable heptose or KDO (results not shown). The presence of ' $O$-phosphorylated KDO' in $B$. gingivalis LPS has recently been reported by Kumada et al. (1988).

The profile of LPS from Bacteroides species in SDS-PAGE stained with ammoniacal silver gave regularly spaced ladder patterns with sugar chain lengths of varying molecular size (Fig. 1). A rather different result has been reported for $B$. gingivalis LPS by Naito et al. (1985), who found broad and heavily staining bands of lower molecular sizes. The presence of closely spaced bands on the silver-stained SDS-PAGE is suggestive of the pattern produced by the smooth type of LPS from Enterobacteriaceae species (Weintraub et al., 1985).

Nair et al. (1983) described LPS from $B$. gingivalis producing a precipitin band against antisera to strains of this species in immunodiffusion. Similar results were obtained in this study using the antiserum to B. gingivalis LPS (Fig. 2). The LPS from other Bacteroides species did not yield a precipitin band under the same experimental condition. Millar et al. (1987) have recently reported that a monoclonal antibody to the LPS of $B$. gingivalis 381 was reactive with LPS from this species, but not with that from other Bacteroides species. Furthermore, antibodies to LPS from $B$. loescheii and $B$. intermedius produced precipitin bands against LPS from these Bacteroides species as well as $B$. oralis and $B$. corporis. These findings clearly show the presence of some common antigen among these species (Fig. 2). The chemical linkage of the polysaccharide portion of these LPS responsible for immunochemical specificity remains to be elucidated. These results seem to indicate that $B$. gingivalis LPS possess a species-specific immunochemical specificity.

Variable results have been reported from different laboratories concerning the immunological and biological activities of LPS of oral and non-oral Bacteroides species using LPS-responsive and nonresponsive murine strains, $\mathrm{C} 3 \mathrm{H} / \mathrm{HeN}$ and $\mathrm{C} 3 \mathrm{H} / \mathrm{HeJ}$, respectively. Joiner et al. (1982) first suggested that the phenol/water-extracted LPS from $B$. fragilis ATCC 23475 stimulated lymphoid cells of both $\mathrm{C} 3 \mathrm{H} / \mathrm{HeN}$ and $\mathrm{C} 3 \mathrm{H} / \mathrm{HeJ}$ mice. Our previous and present results basically coincide with those of Joiner et al. (1982). Nair et al. (1983), on the other hand, reported that $B$. gingivalis 381 LPS was not mitogenic for spleen cells of either mouse strain, although the LPS induced $\mathrm{Ca}^{2+}$ release from organ culture of bones. In their experiments, they included $10 \%(\mathrm{v} / \mathrm{v})$ FCS in the mitogenesis assay system. In our experimental conditions, the incorporation of as much as $10 \%(\mathrm{v} / \mathrm{v})$ FCS suppressed the mitogenic activity of $B$. gingivalis LPS as compared to that in the culture medium without FCS (results not shown). This finding may suggest that at least some batches of FCS contain activity that inhibits the mitogenic potential of $B$. gingivalis LPS. Ulevitch et al. (1979) reported that a serum lipoprotein could bind to LPS, resulting in a decreased endotoxicity of the LPS. Natural antibodies reactive with the test sample of LPS may also participate in this phenomenon.

The possibility that some contaminant may be present in the phenol/water-extracted LPS preparations from Bacteroides species must be considered. In this connection, we found that phenol/water extracts of Fusobacterium nucleatum exhibited a significant mitogenicity in $\mathrm{C} 3 \mathrm{H} / \mathrm{HeJ}$ spleen cell cultures (Okahashi et al., 1988). However, this material contained a relatively high amount of protein $(>5 \%, w / v)$. Repeated extractions of the LPS preparation with hot phenol/water yielded a more refined protein-free LPS preparation that showed 
mitogenic activity in $\mathrm{C} 3 \mathrm{H} / \mathrm{HeN}$ but not $\mathrm{C} 3 \mathrm{H} / \mathrm{HeJ}$ spleen cell cultures (Okahashi et al., 1988). However, even after four repeated extractions with phenol/water, the Bacteroides LPS still induced significant mitogenic responses in $\mathrm{C} 3 \mathrm{H} / \mathrm{HeJ}$ as well as $\mathrm{C} 3 \mathrm{H} / \mathrm{HeN}$ spleen cell cultures. These results suggest that the mitogenic potential of the Bacteroides $\mathrm{LPS}$ in $\mathrm{C} 3 \mathrm{H} / \mathrm{HeJ}$ spleen cell cultures is an intrinsic property of their endotoxic molecule. Another unique property of LPS from Bacteroides species is that polymyxin B does not significantly suppress their mitogenic activities. The structural entity of LPS from Bacteroides species responsible for these properties is not known; the absence of KDO and heptose but possible presence of $O$-phosphorylated KDO in Bacteroides LPS may contribute to differences in biological responses between them and enterobacterial LPS.

The active entity of enterobacterial LPS is endotoxic lipid A, as confirmed recently by extensive studies using synthetic analogues of lipid A (Westphal et al., 1985). The lipid portion of the LPS from bacteria of the Enterobacteriaceae can be isolated from native LPS by mild hydrolysis in $1 \%(\mathrm{v} / \mathrm{v})$ acetic acid at $100{ }^{\circ} \mathrm{C}$ for $2-4 \mathrm{~h}$ (Galanos et al., 1971). Preliminary experiments indicated that hydrolysis in $\mathrm{HCl}$, rather than acetic acid, was the most appropriate method to isolate the lipid portion from Bacteroides LPS. The lipid portion thus obtained exhibited mitogenic responses in both $\mathrm{C} 3 \mathrm{H} / \mathrm{HeN}$ and $\mathrm{C} 3 \mathrm{H} / \mathrm{HeJ}$ spleen cells, although the level of stimulation by the lipid portion was not as high as that induced by the whole LPS.

\section{REFERENCES}

Cunningham, A. J. \& Szenberg, A. (1968). Further improvements in the plaque technique for detecting single antibody-forming cells. Immunology 14, $599-600$.

Daly, C. G., Seymour, G. J. \& Kieser, J. B. (1980). Bacterial endotoxin: a role in chronic inflammatory periodontal disease? Journal of Oral Pathology 9, $1-15$.

Duerden, B. I., GoOdwin, L. \& O'NeIL, T. C. A. (1987). Identification of Bacteroides species from adult periodontal disease. Journal of Medical Microbiology 24, 133-137.

Galanos, C., Lüderitz, O. \& Westphal, O. (1971). Preparation and properties of antisera against the lipid-A component of bacterial lipopolysaccharides. European Journal of Biochemistry 24, 116-122.

HoFstaD, T. (1974). The distribution of heptose and 2-keto-3-deoxy-octonate in Bacteroidaceae. Journal of General Microbiology 85, 314-320.

JOHNE, B. \& BRYN, K. (1986). Chemical composition and biological properties of a lipopolysaccharide from Bacteroides intermedius. Acta pathologica, microbiologica et immunologica scandinavica B94, 265-271.

JOINER, K. A., MCADAM, K. P. W. J. \& KASPER, D. L. (1982). Lipopolysaccharides from Bacteroides fragilis are mitogenic for spleen cells from endotoxin responder and nonresponder mice. Infection and Immunity 36, 1139-1145.

Koga, T., Nishimara, T., Fuitwara, T., Nisizawa, T., Orahashi, N., Noguchi, T. \& Hamada, S. (1985). Biochemical and immunobiological properties of lipopolysaccharide (LPS) from Bacteroides gingivalis and comparison with LPS from Escherichia coli. Infection and Immunity 47, 638-647.

Koga, T., Odaka, C., Moro, I., Fujiwara, T., Nishimara, T., OKahashi, N. \& Hamada, S. (1987). Local Shwartzman activity of lipopolysaccharides from several selected strains of suspected periodontopathic bacteria. Journal of Periodontal Research 22, 103-107.

Kumada, H., Watanabe, K., Umemoto, T., Haishima,
Y., Kondo, S. \& Hisatsune, K. (1988). Occurrence of $O$-phosphorylated 2-keto-3-deoxyoctonate in the lipopolysaccharide of Bacteroides gingivalis. FEMS Microbiology Letters 51, 77-80.

LAEMMLI, U. K. (1970). Cleavage of structural proteins during the assembly of the head of bacteriophage T4. Nature, London 227, 680-685.

MANSheim, B. J., ONDERDONK, A. B. \& KASPER, D. L. (1978). Immunochemical and biologic studies of the lipopolysaccharide of Bacteroides melaninogenicus subspecies asaccharolyticus. Journal of Immunology 120, 72-78.

Mayrand, D. \& Holt, S. C. (1988). Biology of asaccharolytic black-pigmented Bacteroides species. Microbiological Reviews 52, 134-152.

Millar, S. J., Chen, P. B. \& HausmanN, E. (1987). Monoclonal antibody for identification of Bacteroides gingivalis lipopolysaccharide. Journal of Clinical Microbiology 25, 2437-2439.

MoRrison, D. C. (1983). Bacterial endotoxins and pathogenesis. Reviews of Infectious Diseases 5, S733-S747.

Nair, B. C., MayberRy, W. R., Dziak, R., Chen, P. B., Levine, M. J. \& HausmanN, E. (1983). Biological effects of a purified lipopolysaccharide from Bacteroides gingivalis. Journal of Periodontal Research 18, 40-49.

NaIto, Y., OKUDA, K., KaTo, T. \& TAKazoE, I. (1985). Monoclonal antibodies against surface antigens of Bacteroides gingivalis. Infection and Immunity $\mathbf{5 0}$, 231-235.

OKahashi, N., Koga, T., Nishihara, T., Fujiwara, T. \& Hamada, S. (1988). Immunological properties of lipopolysaccharides isolated from Fusobacterium nucleatum and $F$. necrophorum. Journal of General Microbiology 134, 1707-1715.

Slots, J. \& ListGarten, M. A. (1988). Bacteroides gingivalis, Bacteroides intermedius and Actinobacillus actinomycetemcomitans in human periodontal diseases. Journal of Clinical Periodontology 15, 85-93.

TsaI, C. M. \& FrasCh, C. E. (1982). A sensitive silver 
stain for detecting lipopolysaccharides in polyacrylamide gels. Analytical Biochemistry 119, 115-119.

UleVitch, R. J., Johnston, A. R. \& WeINSTEIN, D. B. (1979). New function for high density lipoproteins. Journal of Clinical Investigation 64, 1516-1524.

Weintraub, A., Zähringer, U. \& Lindberg, A. A. (1985). Structural studies of the polysaccharide part of the cell wall lipopolysaccharide from Bacteroides fragilis NCTC 9343. European Journal of Biochemistry 151, 657-661.

WeSTPHAL, O. \& JANN, K. (1965). Bacterial lipopolysaccharides. Extraction with phenol-water and further applications of the procedure. Methods in Carbohydrate Chemistry 5, 83-91.

WestPhal, O., Lüderitz, O., Galanos, C., Mayer, H. \& RieTsCheL, E. T. (1985). The story of bacterial endotoxin. In Advances in Immunopharmacology, pp. 13-34. Edited by L. Chedid, J. W. Hadden, F. Spreafico, P. Dukor \& D. Willoughby. Oxford: Pergamon Press.

WILSON, M., MOORE, J. \& Kieser, J. B. (1986). Identity of limulus amoebocyte lysate-active root surface materials from periodontally involved teeth. Journal of Clinical Periodontology 13, 743-747. 